\title{
Abklärung des Korrosionsmechanismus mittels metallographischer und fraktographischer Methoden an gewalzten AlZnMgCu1.5 Blechen
}

\section{An Elucidation of the Corrosion Mechanism Using Metallographic and Fractographic Methods on Rolled AlZnMgCu1.5 Sheets}

\author{
Rolf Winkler, Markus Faller, Markus Zgraggen
}

Korrespondenzanschrift/Correspondence address:

EMPA - Eidgenössische Materialprüfungs- und Forschungsanstalt, Abteilung Korrosion und Werkstoffintegrität; Überlandstrasse 129; $\mathrm{CH}-8600$ Dübendorf;

E-Mail: rolf.winkler@empa.ch,markus.faller@empa.ch,markus.zgraggen@empa.ch

Eingangen: 25. August 2005

Angenommen: 29. August 2005

\section{Kurzfassung}

Bei hochfesten Aluminiumlegierungen können je nach Werkstoffzustand und/oder Umgebungsbedingungen verschiedene Korrosionsmechanismen zum Versagen von Bauteilen führen. Dies sind Schichtkorrosion, interkristalline Korrosion sowie Spannungsrisskorrosion. Bei Schadensfällen ist die Abklärung der Korrosionsart zur Prävention wichtig. In vielen Fällen ist es daher erforderlich, alle Ergebnisse verschiedener Untersuchungsmethoden in die Interpretation der Ergebnisse einfliessen zu lassen. Im vorliegenden Fall wird von einem Korrosionsschaden an einem Walzblech aus der Al-Legierung 7075 (Zustand T6) berichtet. Der Verdacht, dass das Aufblättern der Bleche durch Schichtkorrosion verursacht wurde, konnte metallographisch nicht bestätigt werden. Der Korrosionsangriff erfolgte entlang der Korngrenzen. Durch mikrofraktographische Untersuchungen an der Rissspitze konnte am Rasterelektronemikroskop interkristalline Korrosion ebenfalls ausgeschlossen werden. Erst durch die Verknüpfung von metallographischen und fraktographischen Untersuchungsmethoden konnte als Schadensmechanismus die Spannungsrisskorrosion eindeutig bestimmt werden.

\section{Einleitung}

Gegenstand der Untersuchungen waren gewalzte Bleche $(s=2.5 \mathrm{~mm})$ aus der Al-Legierung
Received: April 25, 2005

Accepted: April 29, 2005

Translation: J. Fritsche

\section{Abstract}

Various corrosion mechanisms can result in the failure ofcomponentsinhigh-strengthaluminium alloys, depending on the states of the materials and/orenvironmentalconditions. Thosearelayer corrosion, intergranular corrosion cracking, and stress corrosion cracking. For a prevention of future failure, it is necessary to elucidate the corrosion type in damaged components. Therefore, all results obtained from various examination methods require to be gathered in many cases to allow for an interpretation. The present case reports about a damage caused by corrosion to a rolled sheet made of the Al alloy 7075 (T6 condition). The suspicion that the delamination of the metal sheets was due to layer corrosion was not confirmed by metallographic examinations. The corrosive attack occurred along the grain boundaries. Likewise, intergranular corrosion cracking was successfully excluded by microfractographic examinations on the tip of the crack in a scanning electron microscope. It was only by combining the metallographic and fractographic examination methods that stress corrosion cracking was clearly proved to be the damage mechanism.

\section{Introduction}

The examinations were made on rolled sheets ( $\mathrm{s}=2.5 \mathrm{~mm}$ ) made of the Al alloy 7075 (T6 


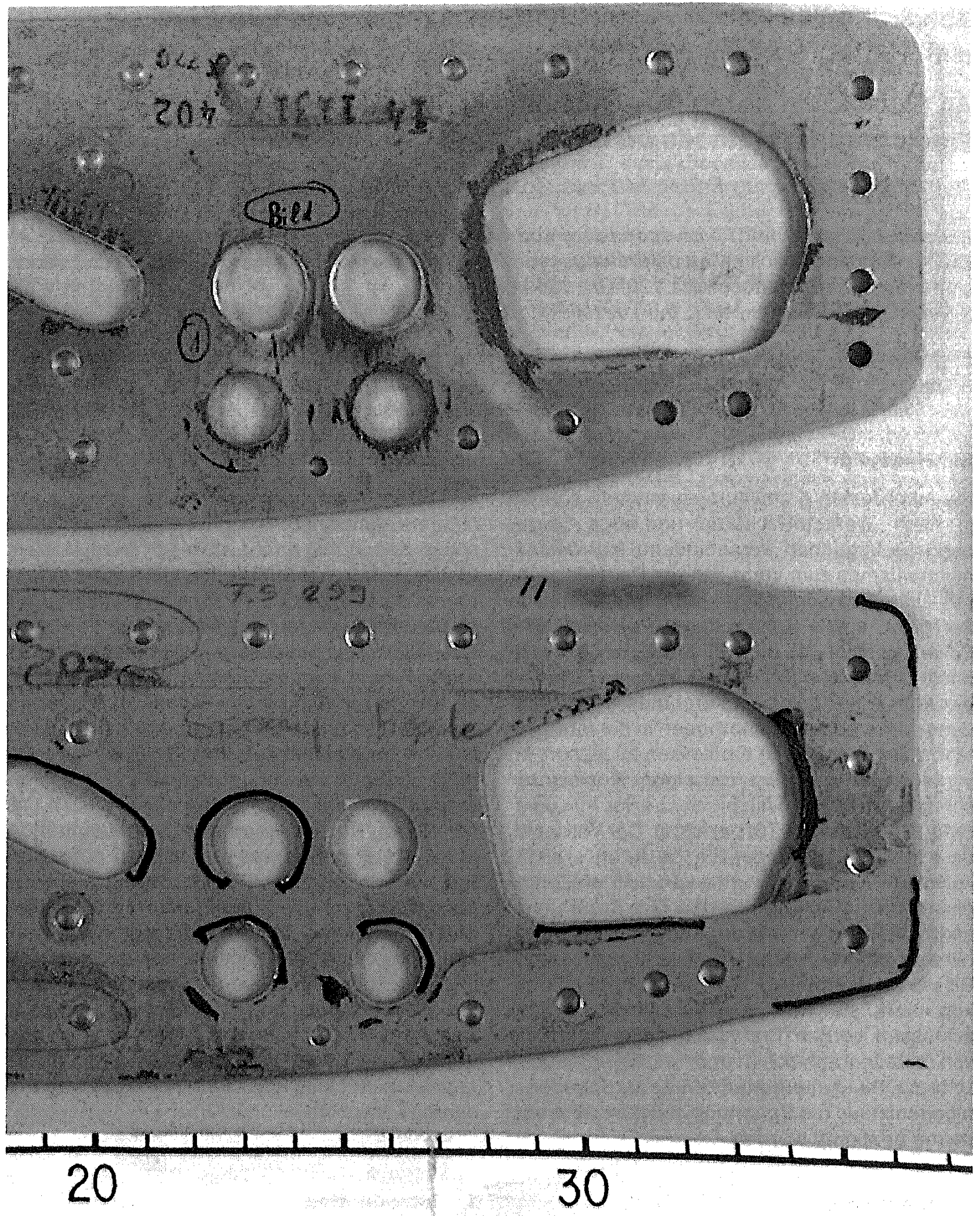

ild 1. Ansicht der Blechabschnitte

ig. 1. A view of the sheet metal portions 
7075 im Zustand T6 (Bild 1). Die Bleche sind Bestandteil von Flugzeugen und haben die Aufgabe, die durch den Tank verursachten Kräfte in die Rumpfstruktur des Fliegers einzuleiten. Nach Ausbau und lokalem Ablaugen der Bauteile wurde mittels Eindringprüfverfahren festgestellt, dass an Aussenkanten und in Bohrungen Risse parallel zur Oberfläche vorhanden sind.

Die Oberflächenbehandlung der Bleche be-

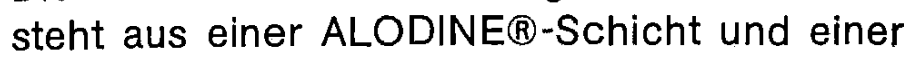
Schicht aus Epoxy Primer. Die Kantenschütze, aus hartem Polymer, werden mit einem Kleber (Chloropren) befestigt.

\section{Untersuchungen}

\subsection{Makroskopisch}

Auf der Stirnseite der Bleche und in den Bohrungen/Ausstanzungen sind feine Anrisse parallel zur Oberfläche zu erkennen. In den Bohrungen sind die Risse nahezu über den gesamten Umfang und in etwa der Blechmitte verteilt (Bild 2). Das schichtartige Aufblättern an einigen Stellen verursachte lokal eine Dickenzunahme des Bleches. Nach Auftrennen derartiger Stellen, senkrecht zur Rissebene, wird der schichtartige Aufbau des Angriffes deutlich (Bild 3).

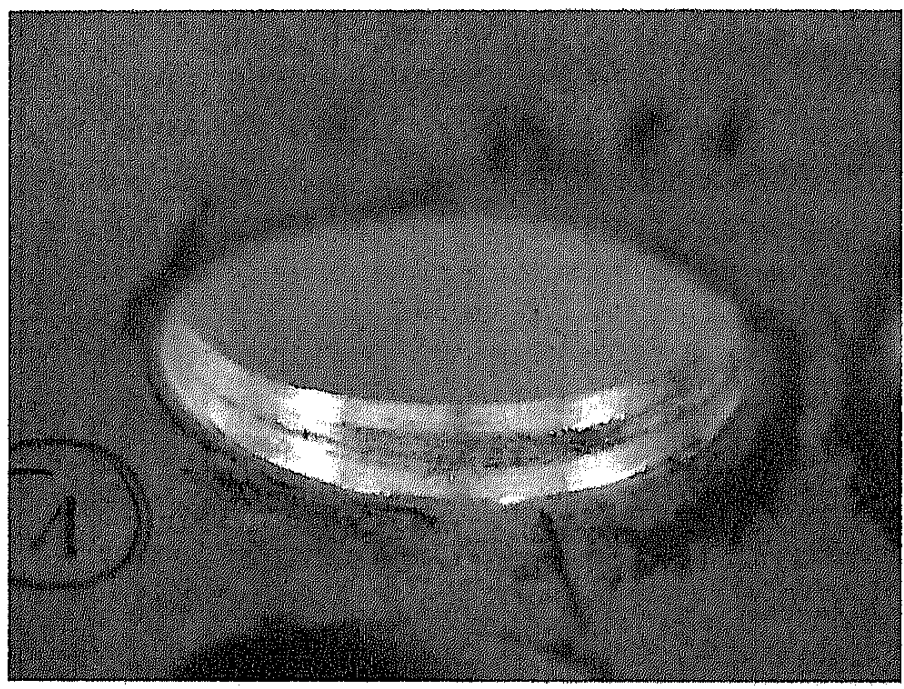

Bild 2. Ansicht einer aufgeblätterten Bohrung in Blechmitte

Fig. 2. A view of a delaminated bore in the sheet centre condition) (Fig. 1). The sheets are components of airplanes and their function is to introduce the forces provoked by the kerosene tank into the fuselage of the airplane. After the components were dismounted and locally leached it was found out by the liquid penetrant test that there were cracks parallel to the surface on outer edges and in bores.

The surface finish of the sheets comprises an ALODINE $\circledast$ coat and a film of epoxy primer. The edge protectors, which are made of a hard polymer, are attached by means of an adhesive (chloroprene).

\section{Examinations}

\subsection{Macroscopically}

The front sides of the sheets and the bores/ punched regions allow to identify fine incipient cracks parallel to the surface. The cracks found in the bores are distributed nearly across the entire circumference and approximately in the sheet centres (Fig. 2). The delamination in layers at some points locally caused an increase in sheet thickness. After such points were separated from each other in a direction perpendicular to the crack plane the layered structure of the attack becomes evident (Fig. 3).

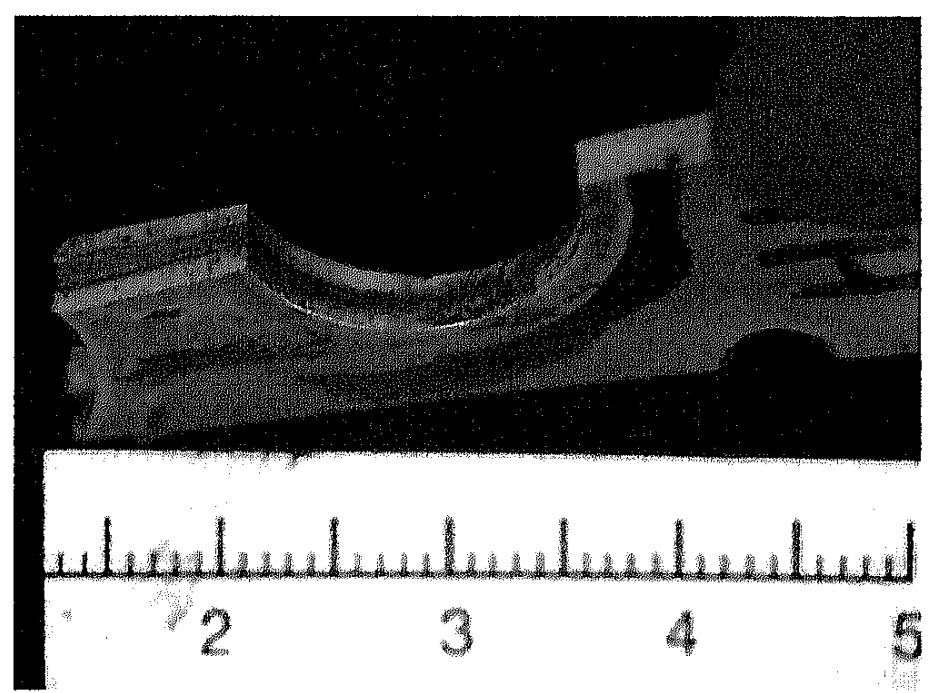

Bild 3. Aufgetrennte Bohrung. Schichtartiges Aufblättern in Blechmitte

Fig. 3. A separated bore with delamination in layers in the sheet centre 


\subsection{Metallographie und Härtemessung}

Quer zur Blechdicke bzw. Rissebene wurden metallographische Schliffe durch die Defektstellen angefertigt. Es liegt ein rekristallisiertes Korngefüge vor. Die Walztextur ist dennoch gut zu erkennen. Der Rissverlauf ist interkristallin, ausgehend von der kaltverformten Randzone. Die Kaltverformungen wurden vermutlich durchs Bohren bzw. Ausstanzen der Löcher eingebracht (Bild 4). Das Schadensbild kann einem Korrosionsmechanismus zugeordnet werden, welchem, ob interkristalline Korrosion oder Spannungsrisskorrosion, kann jedoch mit rein metallographischen Methoden nicht

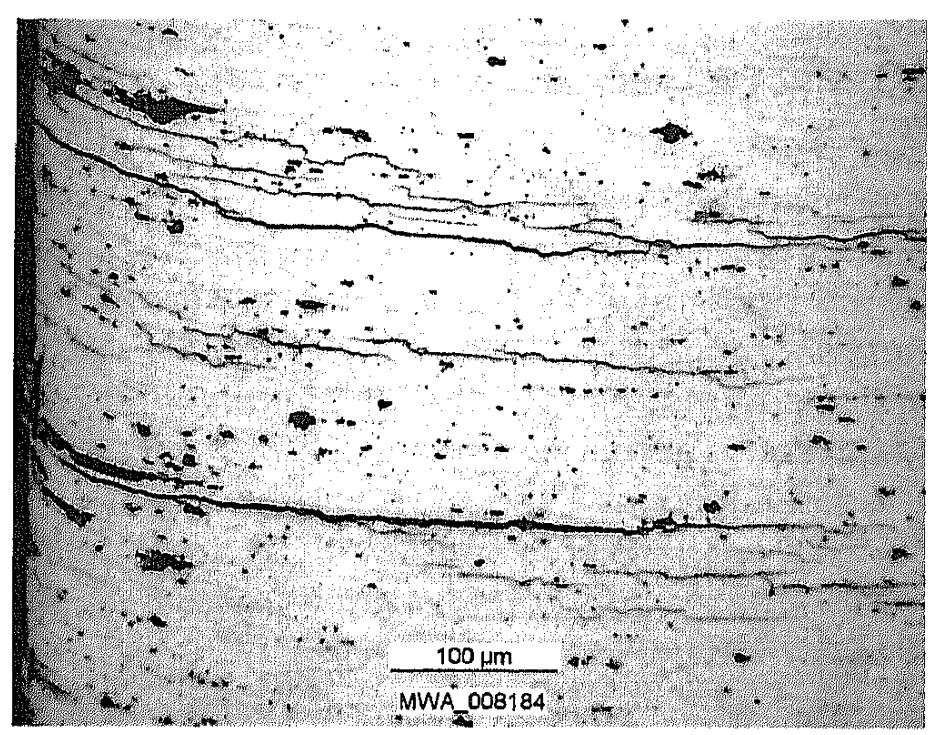

nachgewiesen werden. Schichtkorrosion kann als Korrosionsart ausgeschlossen werden. Schichtkorrosion liegt nur dann vor, wenn der Angriff Seigerungszeilen folgend transkristallin verläuft [1].

Mittels Vickers wurde an den Blechen die Härte bestimmt. Die Prüflast wurde auf $5 \mathrm{~kg}$ begrenzt (HV5). Der Mittelwert aus drei Einzelmessungen (Streuung < 2 HV5) ergab eine Härte von 183 HV5. Dies entspricht einem lösungsgeglühten und warmausgelagerten Werkstoffzustand (T6).

\subsection{Metallography and Hardness Measure- ments}

Metallographic polished sections were made through the defective points crosswise to the sheet thickness and crack plane. There is a recrystallized grain microstructure. Nevertheless, it is easy to recognize the rolling texture. The crack runs intergranularly, starting from the cold-deformed external zone. The colddeformed zones presumably were introduced by drilling or punching the holes (Fig. 4). The failure pattern can be attributed to a corrosion mechanism which, be it layer intergranular corrosion or stress corrosion cracking, cannot be demonstrated by purely metallographic meth-

Bild 4. Interkristalliner Rissverlauf (Kroll-Ätzung), ausgehend von der kaltverformten Randzone

Fig. 4. An intergranular run of cracks (Kroll etching), starting from the cold-deformed external zone

ods. Layer corrosion may be ruled out as a corrosion type. Layer corrosion will only exist when the attack is transgranular and follows the segregation lines [1].

The Vickers technique was employed to determine the hardness of the sheets. The load under testing was limited to $5 \mathrm{~kg}$ (HV5). The mean value obtained from three individual measurements (with a scatter $<2$ HV5) revealed a hardness of 183 HV5. This corresponds to a solution heat treated and artificial aged material condition (T6). 


\subsection{Mikroskopisch}

Die Rissflächen wurden am Rasterelektronenmikroskop (REM) untersucht. Aufgrund der schichtartigen Belegung der Flächen mit Korrosionsprodukten konnten diese nicht verwendet werden. Durch Auftrennen der Risse im Labor (Laborbruch) konnten brauchbare Oberflächen, direkt an der Rissspitze, für die Untersuchungen herangezogen werden. Es zeigte sich, dass im Bereich der Rissspitze die Risse interkristallin verlaufen. Die Korngrenzen sind klaffend und glatt, ohne Grübchenbildung und Belegung mit Korrosionsprodukten (Bild 5). Aufgrund des fraktographischen Befundes ist im vorliegenden Fall die Rissinitierung klar dem Mechanismus der Spannungsrisskorrosion zuzuordnen.

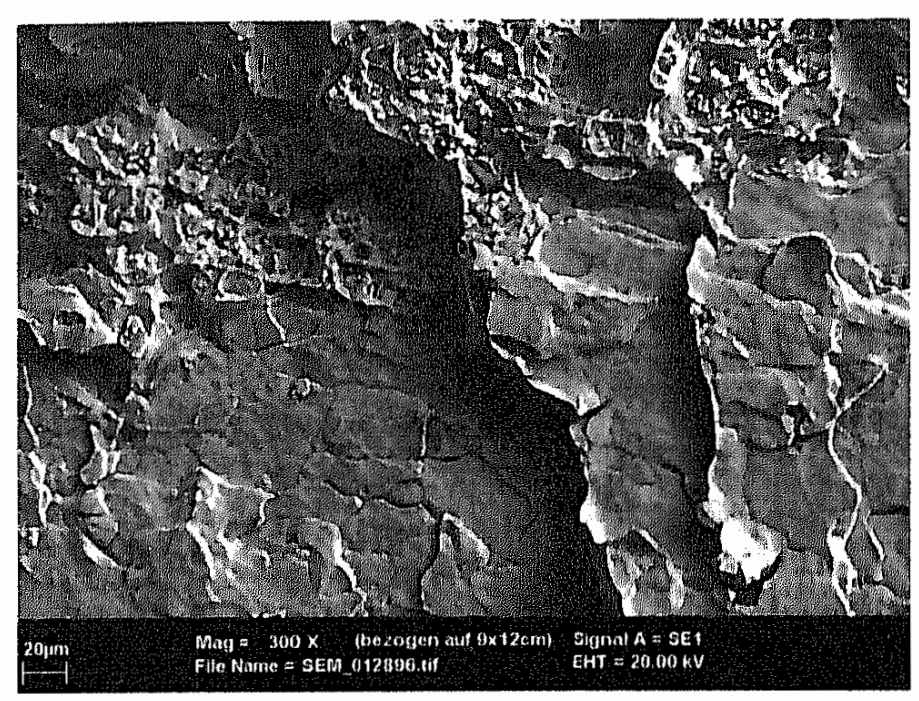

\subsection{Mikroanalytik}

Für die mikroanalytischen Untersuchungen an der Elektronenstrahl Mikrosonde (EMS) wurden rissbehaftete Proben wasserfrei präpariert. In sämtlichen Rissverästellungen in der Umgebung der Rissspitze konnte qualitativ Chlor nachgewiesen werden.

\section{Zusammenfassung}

Untersucht wurden Risse und Aufblätterungen an gewalzten Aluminium-Blechen aus dem Werkstoff 7075 (DIN AlZnMgCu1.5) im Zustand T6. Die Untersuchungen wurden mittels makroskopischer, mikroskopischer und metallographischer Methoden durchgeführt. Metallographisch konnte als Rissursache Korrosion

\subsection{Microscopically}

The cracked areas were examined in a scanning electron microscope (SEM). Since some areas were coated with layers of corrosion products it was impossible to use them. When the cracks were separated into layers at laboratory (laboratory breakup) it became possible to provide surfaces usable for the examinations directly at the crack tips. It was shown that the cracks ran intergranularly in the region of the crack tips. Grain boundaries are gaping and smooth with no formation of dimples and coats of corrosion products (Fig. 5). Based on the fractographic findings, an initiation of cracks clearly is attributable to the mechanism of stress corrosion cracking.

Bild 5. Im Labor geöffnete Rissspitze. Oben Gewaltbruchtläche (Wabenstruktur). Unten interkristalliner Rissverlauf mit klaffenden Korngrenzen. Kornflächen ohne Belegung von Korrosionsprodukten bzw. Grübchenbildung.

Fig. 5. A crack tip as opened at a laboratory. Top: Forced fracture area (dimples). Bottom: An intergranular run of cracks within gaping grain boundaries. Grain surfaces are not coated with corrosion products or dimples.

\subsection{Microanalysis}

Microanalytical examinations on the electron beam micro-probe (EBM) involved a waterless preparation of crack-affected samples. An existence of chlorine was proved qualitatively in all crack ramifications in the regions surrounding the crack tips.

\section{Summary}

Examinations were made on cracks and delaminated areas of rolled aluminium sheets made of material 7074 (DIN AIZnMgCu1.5) in the T6 condition. The examinations were performed by means of macroscopic, microscopic, and metallographic methods. Metallography was successful in determining corrosion as a cause 
entlang der Korngrenzen festgestellt werden. Durch mikrofraktographische Untersuchungen an der Rissspitze (Laborbruch) konnte eindeutig Spannungsrisskorrosion (SpRK) als derverursachende Mechanismus der Rissbildung ermittelt werden.DiemikroanalytischenUntersuchungen in der Rissspitze konnten als aggressives Medium Chlor (Chloride) ausfindig machen.

Härtemessungen ergaben, das die Bleche mit einer Vickers-Härte von 183 HV5 im lösungsgeglühten und warmausgelagerten Zustand (T6) vorliegen.

\section{Diskussion}

AlZnMgCu-Legierungen sind je nach Umgebungsmedium, Bauteilspannungen und Gefügezustand anfällig für Korrosion. Es können folgende Korrosionsarten auftreten:

Schichtkorrosion wird praktisch nur im kaltausgehärteten Zustand beobachtet, erfolgt auch in Abwesenheit von Spannungen und benötigt entweder einen dauernden oder intermittierenden Kontakt mit einer Flüssigkeit. Der Angriff ist von einer starken Zerstörung des Materials begleitet (Abblättern) und die Korrosion verläuft aufgrund von Gussseigerungen überwiegend transkristallin.

Spannungsrisskorrosion hingegen kann sowohl im kalt- wie auch im warmausgehärteten Zustand auftreten. Es verlangt die Anwesenheit von Zugspannungen und kann bereits bei Luftfeuchtigkeit auftreten. Der Korrosionsangriff verläuft ausschliesslich interkristallin.

Die Anfälligkeit hinsichtlich dieser beiden Korrosionsarten ist, ausser von der Zusammensetzung, zudem noch stark von der Glühtemperatur des Gussbarrens abhängig [2].

Interkristalline Korrosion kann praktisch nur bei fehlerhafter Wärmebehandlung auftreten. Dies beinhaltet, dass entweder die Abkühlbedingungen nach dem Lösungsglühen ungünstig waren, oder es wurde in einem ungünstigen Temperaturbereich geglüht.

Da Spannungsrisskorrosion (SpRK) von interkristalliner Korrosion bei hochfesten Al-Legierungen metallographisch häufig nicht zu unter- of cracking along the grain boundaries. Microfractographic examination made at the crack tips (laboratory breakup) allowed to distinctly determine stress corrosion cracking (SCC) as a mechanism causing the formation of cracks. Microanalytical examinations made in the crack tip permitted to locate chlorine (chlorides) as an aggressive medium.

Hardness measurements revealed that the existing sheets are of a Vickers hardness of 183 HV5 in both the solution heat treated and artificial aged conditions (T6).

\section{Discussion}

AlZnMgCu alloys will be susceptible to corrosion, depending on the surrounding medium, component stresses, and microstructural condition. The corrosion types below can occur:

Layer corrosion, which is virtually observed in the naturally aged condition only, also occurs in the absence of stresses, and requires either a permanent or intermittent contact with a liquid. The attack is made concurrently with a heavy destruction of the material (delamination) and corrosion predominantly is transcrystalline because of a segregation of the cast components.

On the contrary, stress corrosion cracking can be found in both the naturally aged and artificial aged conditions. It presupposes the presence of tensile stresses and can occur already when the air is humid. The corrosion attack exclusively is intergranular.

The susceptibility with regard to those two corrosion types, apart from depending on the material composition, is strongly contingent on the annealing temperature of the cast ingot [2].

Intergranular corrosion can virtually appear solely when thermal treatment is faulty. This implies that either the cool-down conditions were unfavourable after the solution annealing procedure or annealing was done within an inappropriate temperature range.

Since stress corrosion cracking (SCC) frequenty cannot be distinguished by metallographic methods from intergranular corrosion crack- 
scheiden ist, können meist nur fraktographische Methoden den sicheren Beweis antreten. Es ist bekannt, dass Wasserstoff der Auslöser von SpRK sein kann, im vorliegenden Fall ist aufgrund der mikroanalytischen Befunde eher von einer Kontamination mit Chloriden auszugehen, zumal mit chlorhaltigen Klebern in der Umgebung des Bauteils gearbeitet wurde. Die nötigen Zugspannungen wurden u.a. fertigungstechnisch (Bohren, Stanzen, etc.) eingebracht.

\section{Literatur/References}

[1] Aluminium-Taschenbuch, 13. Auflage; Aluminium-Verlag GmbH Düsseldorf 1974, S. $108 f f$.

[2] Bassi, G.; Theler, J. J.: Einfluss der Barrenglühtemperatur auf das Gefüge einer ing in high-strength $\mathrm{Al}$ alloys a safe evidence can be provided by fractographic methods in most cases. It is known that hydrogen can be the initiator of SCC but, in the present case, an assumption can be made that there is rather a contamination by chlorides as the microanalytical findings suggest, all the more so as there work was done with chlorine-containing adhesives in the vicinity of the components. The tensile stresses required were introduced, inter alia, by production technological processes (drilling, punching, etc.).

Al-Zn-Mg1-Legierung und auf die Empfindlichkeit gegen Schicht- und Spannungsrisskorrosion der entsprechenden Bleche; Z. Metallkunde (1969) H. 3

\section{MITTEILUNGEN/INFORMATION}

\section{Zusätzliche Analysefunktionen und rascheres Setup}

\section{Materialanalyse und Schichtdickenmessung mit Röntgenfluoreszenz}

Die Helmut Fischer GmbH + Co. KG in Sindelfingen stellt für Anwender von FISCHERSCOPE $(\mathbb{B}$ $X$-RAY-Messgeräten eine neue Version des umfangreichen Mess- und Auswerteprogramms WinFTM(B) V.6 vor. Insbesondere für Anwender in der Qualitätskontrolle, im Wareneingang und in Analytik-Laboratorien bietet sie bessere Analysefunktionen und ein schnelleres Setup der Messungen.

Besonders vorteilhaft ist die automatische Elementerkennung in Spektren aus Proben unbekannter Zusammensetzung. Wesentlich schneller als bisher können die charakteristischen Peaks in den Fluoreszenzspektren den jeweiligen Elementen durch die neue Automatikfunktion „peak fit" zugeordnet werden. Die Energieauflösung dieser Geräte ist ausreichend hoch, so dass die Peaks der enthaltenen Elemente in den Spektren getrennt sind und damit sehr gut zugeordnet werden können.

Weiterer Vorteil der Software WinFTM(8) V.6 ist die raschere Auswertung wiederkehrenderRou-
tine-Messungen. Dazu vergleicht die Software nach einer kurzen Pilot-Messung das erhaltene Spektrum mit bereits gespeicherten Spektren, die unter ähnlichen Messeinstellungen ermittelt wurden.

Will ein Anwender Spektren manuell auswerten, können künftig bis zu 27 Spektren parallel geladen und am Bildschirm angezeigt werden. Das vereinfacht und beschleunigt den Vergleich einer Vielzahl unterschiedlicher Proben und Messungen. Die einzelnen Spektren lassen sich übersichtlich und bequem ein- und ausblenden. Wahlweise lässt sich auch ein beliebiges Bezugsspektrum zu den auszuwertenden Spektren anzeigen.

Informationen:

Helmut Fischer GmbH + CO. KG, IndustriestraBe 21, D- 71069 Sindelfingen Tel.: (0 70 31) 303 0, Fax: (0 70 31) 30379 , E-Mail:mail@Helmut-Fischer.de Internet: www.Helmut-Fischer.com 